\title{
PENGARUH KUALITAS PELAYANAN BANQUET TERHADAP KEPUASAN KONSUMEN PADA LABERSA GRAND HOTEL \& CONVENTION CENTER SIAK HULU KAMPAR
}

\author{
Oleh \\ ${ }^{1)}$ Nova Syafrina ${ }^{2)}$ Syaiful Akbar \\ ${ }^{1)}$ S) Sekolah Tinggi Ilmu Ekonomi Riau \\ Jalan HR. Subrantas No 57 Panam-Pekanbaru \\ ${ }^{1)}$ Email: nova.syafrina80@gmail.com \\ ${ }^{2)}$ Email: syaifula@gmail.com
}

\begin{abstract}
Abstrak
Penelitian ini dilakukan di Labersa Grand Hotel \& Convention Center, Siak Hulu, Kampar. Tujuan penelitian ini adalah untuk mengetahui apakah ada pengaruh yang signifikan antara kualitas pelayanan terhadap kepuasan konsumen pada Labersa Grand Hotel \& Convention Center, Siak Hulu, Kampar. Populasi yang ada dalam penelitian ini sebanyak 1.317 orang. Dalam penelitian ini pengambilan sampel menggunakan asidental sampling, yaitu sebesar 93orang. Data yang digunakan adalah data primer dan sekunder dengan analisis menggunakan regresi linier sederhana. Hasil penelitian menunjukan bahwa hasil regresi linier adalah $Y=16,974+0,642 X$ yaitu memiliki arah hubungan yang positif, dan dan variabel kualitas pelayanan berpengaruh signifikan terhadap kepuasan konsumen hal tersebut dapat dilihat nilai nilai t_hitung $(7,722)>$ dari t_tabel (1,98638). sedangkan besarnya pengaruh kualitas pelayanan terhadap kepuasan konsumen adalah sebesar 39,6 persen sedangkan sisanya sebesar 60,4 persen menggambarkan variabel bebas lainnya yang tidak diamati dalam penelitian ini.
\end{abstract}

Kata Kunci : Kualitas Pelayana, Kepuasan Konsumen

\begin{abstract}
This research was conducted at Labersa Grand Hotel \& Convention Center, Siak Hulu, Kampar. The purpose of this study was to determine whether there was a significant effect between the quality of service on customer satisfaction at Labersa Grand Hotel \& Convention Center, Siak Hulu, Kampar. The population in this study was 1,317 people. In this study the sampling uses incidental sampling, which is equal to 93 people. The data used are primary and secondary data with analysis using simple linear regression. The results showed that the linear regression results were $Y=16,974+0,642 X$ which has a positive relationship direction, and the service quality variable has a significant effect on customer satisfaction. It can be seen the value of t-count $(7,722)>$ from $t$-table $(1,98638)$. while the magnitude of the effect of service quality on consumer satisfaction is 39.6 percent while the remaining 60.4 percent describes other independent variables not observed in this study. Keywords: Service Quality, Consumer Satisfaction
\end{abstract}

\section{PENDAHULUAN}

Banquet dalam terjemahan bahasa indonesia berarti perjamuan. Sedangkan arti banquet adalah pelayanan suatu acara yang sudah dipesan dan direncanakan sebelumnya melingkupi pelayanan makanan dan minuman, ruangan dan kelengkapan peralatan yang dibutuhkan dalam waktu tertentu.

Pada Hotel, banquet memiliki bagian tersendiri dalam suatu susunan departemen dan masih dalam lingkup F\&B Department yang bertugas untuk menangani segala macam kegiatan pesta atau jamuan yang diselenggarakan oleh suatu panitia atau pihak lain yang membuat pesanan ke hotel. Departemen banquet memiliki peranan penting dalam hal pelayanan jasa penyelenggaraan acara yang diadakan oleh hotel. Banquet tidak jauh berbeda dengan restoran baik perlengkapan, peralatan serta tata saji yang disuguhkan, hanya saja banquet tidak menyediakan sajian secara permanen, melainkan diselenggarakan setelah adanya pihak pemesanan yang akan menyelenggarakan acara. Pelayanan pada banquet dimulai sejak pelanggan memesan tempat hingga akhir acara. 
Acara-acara yang dapat diselenggarakan oleh departmen banquet: pesta pernikahan, pesta ulang tahun/hari jadi, seminar, pelatihan, konferensi dan rapat, teater dan Bazar, dan acara keluarga dan makan-makan bersama. Untuk memulai pekerjaannya, departemen banquet menerima dokumen BEO (Banquet Event Order) yang berisikan acara yang sudah dipesan tamu. Dokumen BEO berisikan informasi nama pelanggan, jenis acara, tanggal, waktu, ruang, jumlah tamu dan juga hal yang diinginkan tamu untuk dipersiapkan. Berdasarkan hal tersebut, departemen banquet bisa memulai melakukan persiapan suatu acara.

Hotel adalah satu bisnis usaha yang bergerak dibidang jasa. Dimana pelayanan merupakan inti pokok dari penjualan hotel yang diberikan kepada tamu. Memberikan pelayanan yang prima adalah salah satu kegiatan hotel, tujuan menerapkan pelayanan yang prima tersebut yaitu untuk meningkatkan volume penjualan hotel.

Hotel sangatlah bergantung pada tamu. Perusahaan perhotelan harus menyadari bahwa pelanggan tidak peduli dan tidak mau tahu tentang masalah yang ada di dalam internal perusahaan, yang terpenting bagi tamu adalah tamu mendapatkan apa yang mereka butuhkan di hotel dan tamu juga tidak mau tau apakah karyawan hotel itu harus bekerja keras atau tidak.

Untuk membuat pelanggan tetap senang dan merasa puas, perusahaan perhotelan harus tahu bagaimana cara menyenangkan tamu. Salah satunya dengan mempertimbangkan apa yang menjadi pendapat tamu atau menanggapi setiap keluhan pelanggan. Maka dengan sendirinya tamu pun akan merasa senang dengan pelayanan yang kita berikan. Begitu pula dalam dunia perhotelan banyak hal yang ditawarkan oleh pihak hotel itu semua merupakan produk-produk hotel, contohnya penginapan, makanan, dan minuman, serta pelayanan lainnya.

Berdasarkan kamus pariwisata dan perhotelan banquet adalah suatu resepsi mewah yang diadakan di ruangan khusus dari hotel, dengan menyediakan makanan mewah dan juga fasilitas lainnya. Dengan kata lain fungsi dan peranan banquet adalah memberikan pelayanan jamuan makan berupa penyediaan makanan, penyediaan peralatan perlengkapan makan, pengaturan susunan dan penataan meja/kursi serta menyediakan tempat/ruangan yang sesuai dengan acara yang akan diselenggarakan. Sehingga para tamu baik yang menyelenggarakan maupun yang di undang merasa nyaman dan juga mendapat pelayanan yang memuaskan selama berada di hotel.

Didalam dunia bisnis, persaingan merupakan hal yang tidak asing lagi terjadi. Pertumbuhan hotel semakin meningkat khususnya di kota Pekanbaru, hal ini tentu saja akan mengakibatkan persaingan yang ketat antara para pemilik hotel,baik itu hotel besar, hotel menengah maupun hotel kecil. Untuk mengatasi persaingan tersebut, hotel harus selalu memberikan memberikan pelayanan dan fasilitas yang prima. Memperlakukan tamu berbeda dengan hotel-hotel lain dan memberikan suatu pengalaman yang sangat menarik kepada tamu, hal ini dapat membuat tamu menjadi percaya dan tetap setia karena merasa puas atas kinerja dan pelayanan yang di berikan.

Seorang pelanggan memiliki memori kolektif, yang sendirinya dibentuk oleh pengalaman per orang. Dengan adanya pengalaman yang menarik terhadap pelayanan tersebut, maka dengan sendirinya dapat menciptakan suatu keyakinan dalam diri tamu atas kinerja hotel, maka akan terbentuk suatu relasi antara penyedia jasa dan tamu.

Hotel adalah suatu bentuk akomodasi yang dikelola secara komersial, disediakan bagi setiap orang untuk memperoleh pelayanan dan penginapan berikut makan dan minum (SK Mentri Perhubungan No.Pm.10/Pw.301/Phb.77). Menurut SK Menteri Perhubungan No. 241/ii/1970/ hotel adalah perusahaan yang menyediakan jasa dalam bentuk akomodasi serta menyediakan hidangan dan fasilitas lainnya didalam hotel untuk umum yang memenuhi syarat comfort dan bertujuan komersial dalam jasa tersebut (STP<Bandung 1992. Hotel adalah suatu jenis akomodasi yang menggunakan sebagian atauseluruh area bangunan untuk 
menyediakan jasa pelayanan dan penginapan,makan, minum serta jasa lainnya bagi umum yang dikelola secara komersial (SK Menparpostel No. Km. 34/NK.103/MPPT 87).

Sementara berdasarkan SK Menparpostel no. 34/hk.103/mmpt-87 pengertian hotel adalah suatu jenis organisasi yang mempergunakan seluruh atau sebagian bangunan untuk menyediakan pelayanan penginapan, makan, dan minum serta jasa lainnya bagi umum yang dikelola secara komersial serta memenuhi ketentuan persyaratan yang ditetapkan dalam keputusan pemerintah.

Berikut sedikit gambaran fasilitas banquet yang terdapat pada Labersa Grand Hotel \& Convention Center, Siak Hulu, Kampar dapat dilihat pada tabel 1 di bawah ini :

Tabel 1 Fasilitas Banquet yang terdapat pada Labersa Grand Hotel \& Convention Center, Siak Hulu, Kampar

\begin{tabular}{|c|c|c|c|c|c|c|c|c|}
\hline \multirow[b]{2}{*}{ No } & \multirow[b]{2}{*}{ Nama Ruangan } & \multirow[b]{2}{*}{ Posisi Lantai } & \multirow[b]{2}{*}{$\begin{array}{c}\text { Ukuran } \\
\text { m2 }\end{array}$} & \multicolumn{5}{|c|}{ Kapasitas } \\
\hline & & & & Cocktail & Theater & $\begin{array}{l}\text { Class } \\
\text { Room }\end{array}$ & $\begin{array}{c}\text { Round } \\
\text { Table }\end{array}$ & U Shape \\
\hline 1 & Ballroom Siak I & Lantai 1 & 936 & 1500 & 800 & 500 & 400 & 300 \\
\hline 2 & Ballroom Siak II & Lantai 1 & 936 & 1500 & 800 & 500 & 400 & 300 \\
\hline 3 & Ballroom Siak III & Lantai 1 & 936 & 1500 & 800 & 500 & 400 & 300 \\
\hline 5 & Meeting Room I & Lantai 2 & 80 & 80 & 50 & 30 & 40 & 28 \\
\hline 6 & Meeting Room II & Lantai 2 & 80 & 80 & 50 & 30 & 40 & 28 \\
\hline 7 & Meeting Room III & Lantai 2 & 80 & 80 & 50 & 30 & 40 & 28 \\
\hline 8 & Meeting Room IV & Lantai 2 & 80 & 80 & 50 & 30 & 40 & 28 \\
\hline 9 & Meeting Room V & Lantai 2 & 80 & 80 & 50 & 30 & 40 & 28 \\
\hline 10 & Meeting Room VI & Lantai 2 & 80 & 80 & 50 & 30 & 40 & 28 \\
\hline
\end{tabular}

Sumber : Labersa Grand Hotel \& Convention Center, 2019.

Berdasarkan tabel 1 dapat dilihat ada 6 ruangan meeting dan ada 3 ruang meeting yang dapat digabungkan, dan terdapat 3 ruang pesta/ballroom yang dapat digabungkan menjaadi satu dan berubah nama menjadi Grand Ballroom. Dengan masing-masing kapasitas tergantung dengan lay out permintaan dari tamu, seperti Ballroom Siak I,II,\&III dengan lay out Cocktail dapat menampung 1500, Theater 800 orang, Class Room 500 orang, Round Table 400 orang, U Shape 300 orang. Pada masing-masing Meeting Room I,II,III,IV,V, \& VI dengan lay out Cocktail dapat menampung 80 orang, Theater 50 orang, Class Room 30 orang, Round Table 40 orang, dan U Shape 28 orang.

Untuk melihat perkembangan tingkat penjualan pelayanan Banquet pada Labersa Grand Hotel \& Convention Center, Siak Hulu, Kampar dapat dilihat pada tabel 2 di bawah ini :

Tabel 2. Target dan Realisasi Pemakaian Ruangan Banquet pada Labersa Grand Hotel \& Convention Center, Siak Hulu, Kampar

\begin{tabular}{|c|c|c|c|c|c|c|c|c|}
\hline \multirow{2}{*}{ No } & \multirow{2}{*}{ Tahun } & \multicolumn{2}{|c|}{$\begin{array}{c}\text { Ruang Pesta/ } \\
\text { Ballroom }\end{array}$} & \multirow{2}{*}{ (\%) } & \multicolumn{2}{|c|}{ Ruang Meeting } & \multirow{2}{*}{$(\%)$} & \multirow{2}{*}{$\begin{array}{c}\text { Total } \\
\text { Realisas }\end{array}$} \\
\hline & & Target & Realisasi & & Target & Realisasi & & \\
\hline 1 & 2014 & 450 & 382 & $84,8 \%$ & 900 & 730 & $81,1 \%$ & 1.112 \\
\hline 2 & 2015 & 500 & 423 & $84,6 \%$ & 950 & 764 & $80,4 \%$ & 1.187 \\
\hline 3 & 2016 & 550 & 458 & $83,2 \%$ & 1.000 & 858 & $85,8 \%$ & 1.316 \\
\hline 4 & 2017 & 650 & 437 & $67,2 \%$ & 1.050 & 808 & $76,9 \%$ & 1.245 \\
\hline 5 & 2018 & 650 & 498 & $76,6 \%$ & 1.050 & 819 & $78 \%$ & 1.317 \\
\hline \multicolumn{2}{|c|}{ Total } & 2.800 & 2.198 & $78,5 \%$ & 4.950 & 3.979 & $80,3 \%$ & 6.177 \\
\hline
\end{tabular}

Sumber : Labersa Grand Hotel \& Convention Center, 2019 
Tabel 2 menjelaskan bahwa jumlah pemakaian ruang pesta/ Ballroom dan ruang meeting dari tahun ke tahun mengalami perubahan, bahwa total pemakaian ruang pesta/Ballroom dari tahun 2014 - 2018 sebesar 2.198 kali ruangan terpakai dan pemakaian ruang meeting dari tahun 2014 - 2018 sebesar 3.979 kali ruangan terpakai. Total pemakaian ruangan pesta dan ruangan meeting dari tahun 2014 - 2018 sebanyak 6.177 kali ruangan terpakai. Dapat kita lihat pemakaian total ruangan pesta/ballroom paling tinggi terjadi pada tahun 2018 dengan total pemakaian 498 kali dan ruang meeting paling tinggi terjadi pada tahun 2016 total ruangan terpakai sebanyak $858 \mathrm{kali}$, sedangkan total pemakaian ruangan pesta/ballroom paling rendah terjadi pada tahun 2014 dengan total pemakaian sebanyak 382 kali dan pemakaian ruangan meeting paling rendah terjadi pada tahun 2014 dengan total $730 \mathrm{kali}$.

Selain dari tabel target dan realisasi serta tabel fasilitas, terdapat pula tabel data keluhan pelanggan pada Labersa Grand Hotel \& Convention Center Kampar sehingga upaya yang dilakukan oleh perusahaan adalah dengan memperhatikan kualitas pelayanan yang terdiri dari: tangible (bukti fisik), reliability (kehandalan), respponsiveness (tanggapan), assurance (jaminan), dan emphaty (empati). Berdasarkan wawancara yang dilakukan oleh penulis terhadap konsumen pada Labersa Grand Hotel \& Convention Center Kampar terdapat beberapa keluhan pelanggan dianaranya sebagai berikut :

Tabel 3 Data keluhan pelanggan pada Labersa Grand Hotel \& Convention Center Kampar

\begin{tabular}{|l|l|}
\hline No & Keluhan Pelanggan \\
\hline 1. & Hotel yang jauh dari bandara dan pusat kota \\
\hline 2. & Kursi acara tidak seragam dan ada yang rusak \\
\hline 3. & Panggung yang digunakan untuk acara goyang atau tidak kokoh \\
\hline 4. & Sound sistem bermasalah, kadang mic tidak berfungsi \\
\hline 5. & Kurangnya responsibiliti karyawan hotel terhadap tamu \\
\hline 6. & Pada saat gladi resik tidak di hidupkan pendingin ruangan Ballroom/Meeting room \\
\hline 7. & Variasi menu yang disediakan terlalu sedikit. \\
\hline
\end{tabular}

Sumber : Labersa Grand Hotel \& Convention Center Kampar,2019

Berdasarkan pada tabel 3 terdapat beberapa keluhan-keluhan pelanggan sehingga pihak manajemen perusahaan dapat merencanakan strategi yang lebih baik di masa yang akan datang dan lebih meningkatkan kualitas pelayanan agar dapat memenuhi keinginan konsumen serta meminimalisasikan keluhan dan meningkatkan konsumen.

Atas dasar pemikiran diatas, sebagai upaya ikut memberi solusi, penulis tertarik untuk melakukan penelitian dengan judul : "Pengaruh Kualitas Pelayanan Banquet Terhadap Kepuasan Konsumen Pada Labersa Grand Hotel \& Convention Center Kampar”

\section{Perumusan Masalah}

Berdasarkan latar belakang masalah diatas, maka pokok permasalahan yang penulis teliti adalah: "Apakah kualitas pelayanan banquet berpengaruh terhadap kepuasan konsumen pada Labersa Grand Hotel \& Convention Center Kampar?"

\section{Tujuan Penelitian}

Tujuan penelitian ini adalah untuk mengetahui pengaruh kualitas pelayanan banquet terhadap kepuasan konsumen Di Labersa Grand Hotel \& Convention Center. 


\section{Penelitian Terdahulu}

Andi Sanjaya (2017), Sekolah Tinggi Ilmu Ekonomi Riau (STIER), dengan judul "Pengaruh Kualitas Pelayanan Terhadap Kepuasan Konsumen Pada PT. First Indo American Leasing Cabang Pekanbaru". Rumusan masalah penelitian ini adalah apakah kualitas pelayanan berpengaruh signifikan terhadap kepuasan konsumen pada PT. First Indo American Leasing Cabang Pekanbaru. Metode penelitian yang digunakan adalah bersifat deskriptif dengan pendekatan kuantitatif. Adapun populasi pada penelitian ini adalah konsumen PT. First Indo American Leasing Cabang Pekanbaru sebanyak 540 orang. Adapun teknik pengambilan sampel dengan menggunakan sampling asidental, maka sampel yang diambil menggunakan rumus slovin sebanyak 84 orang. Teknik analisis data yang digunakan adalah regresi linear sederhana dengan uji hipotesis uji t. Berdasarkan hasil penelitian menyatakan bahwa kualitas pelayanan $(\mathrm{X})$ berpengaruh signifikan terhadap kepuasan konsumen pada PT. First Indo American Leasing Cabang Pekanbaru. Hal ini dapat dilihat $t_{\text {hitung }} 7,670>\mathrm{t}_{\text {tabel }}$ 1,989 dengan tingkat signifikan 0,000 lebih kecil dari 5\%. Maka Ho ditolak dan Ha diterima, artinya variabel kualitas pelayanan $(\mathrm{X})$ berpengaruh signifikan terhadap kepuasan konsumen (Y) pada PT. First Indo American Leasaing Cabang Pekanbaru. Nilai r-square (koefisien determinasi) diperoleh sebesar 0,418. Hal ini menunjukkan bahwa kualitas pelayanan memberikan kontribusi sumbangan berpengaruh terhadap kepuasan konsumen pada PT. First Indo American Leasing Cabang Pekabaru sebesar 41,8\%, sedangkan sisanya sebesar $(100 \%-41,8 \%)=58,2 \%$ dipengaruhi oleh variabel lain diluar variabel dalam penelitian ini.

Menurut Boyd, dkk (2000:4) dalam (Manik, 2016) pemasaran adalah suatu proses yang melibatkan kegiatan-kegiatan penting yang memungkinkan individu dan perusahaan mendapatkan apa yang mereka butuhkan dan inginkan melalui pertukaran dengan pihak lain. Ade Rosita Lakmi, 2015, Universitas Udayana dengan judul "Pengaruh Kualitas Pelayanan Terhadap Kepuasan Masyarakat Pada Rumah Sakit Umum Daerah Bandung" RSUD Bandung merupakan salah satu rumah sakit pemerintah di Bali berusaha memberikan pelayanan kesehatan yang baik pada pelayanan kesehatan yang diberikan. Tujuan penelitian ini adalah analitik korelasional. Teknik sampel yang digunakan adalah proportionate stratified random sampling menggunakan jumlah sampel 60 responden. Pengumpulan data menggunakan kuisioner. Teknik analisa data menggunakan analisis regresi linera sederhana. Hasil penelitian menunjukkan bahwa ada pengaruh yang signifikan antara kualitas pelayanan terhadap tingkat kepuasan masyarakat RSUD Bandung dengan persamaan regresi $\mathrm{Y}=9,938$ $+0,379 \mathrm{X}$ nilai korelasi $(\mathrm{f})=0,399$ dan besarnya pengaruh kualitas pelayanan terhadap tingkat kepuasan masyarakat sebesar 12,9\%. Dari hasil pengujian uji $\mathrm{t}$ diperoleh hasil $\mathrm{t}_{\text {hitung }}=$ 2,926 lebih besar dari $t_{\text {tabel }}=1,6$, maka Hi diterima. Ini berarti pada tingkat kesalahan 5 persen, kualitas pelayanan berpengaruh signifikan terhadap tingkat kepuasan masyarakat pada RSUD Bandung.

Shinta Catur Wulandari (2016), Sekolah Tinggi Ilmu Ekonomi Riau (STIER), dengan judul "Pengaruh Kualitas Pelayanan Terhadap Kepuasan Pelanggan Pada PT. Ibrahim Abdullah Budi Mulia Cabang Pekanbaru". Jumlah sampel dalam penelitian ini sebanyak 68 orang. Hasil penelitian ini adalah kualitas pelayanan memiliki pengaruh positif dan signifikan terhadap kepuasan pelanggan. Alat uji yang digunakan dalam penelitian ini menggunakan regresi linear sederhana, uji t, serta untuk mengetahui besarnya pengaruh variabel menggunakan koefisien determinasi (R2). Dalam uji validitas keseluruhan item pernyataan dinyatakan valid karena diperoleh nilai $r_{\text {hitung }}>r_{\text {tabel. }}$. Hasil regresi linear sederhana diperoleh $\mathrm{Y}=9,062+0,299 \mathrm{X}$. Dari hasil uji secara parsial atau uji $\mathrm{t}$ diperoleh nilai $\mathrm{t}_{\text {hitung }}(4,926)>\mathrm{t}_{\text {tabel }}$ $(1,996)$ artinya variabel kualitas pelayanan berpengaruh positif dan signifikan terhadap variabel kepuasan pelanggan. Dan nilai koefisien determinasi $\left(\mathrm{R}^{2}\right)$ sebesar 0,269 atau 26,9\% 
artinya pengaruh atau kontribusi yang diberikan oleh variabel kualitas pelayanan terhadap kepuasan pelanggan sebesar $26.9 \%$ sedangkan sisanya sebesar $73,1 \%$ dipengaruhi oleh faktor lain yang tidak di teliti dalam penelitian ini.

\section{TINJAUAN PUSTAKA DAN HIPOTESIS \\ Pemasaran}

Menurut American Marketing (AMA) dalam kotler (2009:5) pemasaran adalah suatu fungsi organisasi dan serangkaian proses untuk menciptakan, mengkomunikasikan, dan memberikan nilai kepada pelanggan dan untuk mengelola hubungan pelanggan dengan cara yang menguntungkan organisasi dan pemangku kepentingannya. Menurut Kotler dalam Andi Sanjaya (2017:11) pemasaran adalah sebuah proses kemasyarakatan dimana individu dan kelompok memperoleh apa yang mereka butuhkan dan inginkan dengan menciptakan, menawarkan, dan secara bebas mempertukarkan produk jasa yang bernilai dengan orang lain. Menurut Sumarni dan Soeprihantono (2010:261) pemasaran adalah suatu sistem dari keseluruhan dan kegiatan bisnis yang di tunjukkan untuk merencanaka, menentukan harga, dan mendistribusikan barang dan jasa yang memuaskan kebutuhan baik kepada pembeli maupun yang potensial.

Konsep Pemasaran Kotler tersebut menekankan pada nilai pelanggan yang harus dikomunikasikan kepada pasar sasaran dengan lebih efektif dibandingkan dengan pesaing pesaing lainnya. Konsep Pemasaran Kotler tersebut memiliki maksud yang hampir sama dalam Kotler dan Gary Armstrong ( $2001: 23$ ) yang mengatakn bahwa : "Untuk mencapai tujuan organisasi tergantung pada penentuan kebutuhan dan keinginan pasar sasaran (Target Market) dan memuaskan pelanggan secara lebih efektif dan efisien daripada yang dilakukan oleh pesaing.

\section{Kualitas Pelayanan}

Menurut Moenir (2006:16) pelayanan adalah proses pemenuhan kebutuhan aktifitas orang lain yang langsung karena untuk memenuhi berbagai kebutuhan hidupnya, manusia senantiasa berusaha baik melalui aktifitas sendiri maupun secara tidak langsung melalui aktifitas orang lain. Selanjutnya menurut Lukman (2000:5) pelayanan merupakan suatu kegiatan yang terjadi dalam interaksi langsung antara seseorang dengan orang lain atau mesin secara fisik, dan menyelesaikan kepuasan pelanggan. Menurut Batinggi dan Badu Ahmad (2013:2) pelayanan adalah kunci keberhasilan dalam berbagai usaha atau keinginan yang bersifat jasa. Peranannya akan lebih besar dan bersifat menentukan manakala kegiatankegiatan jasa di masyarakat itu terdapat kompetensi dalam usaha merebut pasar dan langganannya. Sedangkan pandangan Kotler (Hermanto, Apriansyah, Fikri, \& Albetris, 2019) kualitas pelayanan adalah pelayanan yang diberikan kepada pelanggan sesuai dengan standar pelayanan yang telah dibakukan sebagai pedoman dalam memberikan layanan (Kotler, 2009:116).

Menurut Tjiptono (2008:136-137) ada empat karakteristik pelayanan terdiri dari yaitu :

a) Intangibiblity (tidak berwujud)

b) Inseparability (tidak dapat dipisahkan)

c) Variability (berubah-ubah dan bervariasi)

d) Perishability (cepat hilang, tidak tahan lama)

Menurut Kotler (2000:25) kualitas pelayanan merupakan totalitas dari bentuk karakteristik barang dan jasa yang menunjukkan kemampuannya untuk memuaskan kebutuhan pelanggan, baik yang nampak jelas maupun yang tersembunyi. Bagi perusahaan yang bergerak di sektor jasa, pemberian pelayanan yang berkualitas pada pelanggan 
merupakan hal mutlak yang harus dilakukan apabila perusahaan ingin mencapai keberhasilan. Menurut Parasuraman dan Lupiyoadi (2001:148) mengemukakan bahwa kualitas layanan adalah seberapa jauh perbedaan antara kenyataan dan harapan pelanggan atas layanan yang mereka terima/peroleh.

Menurut Parasuraman dalam Sangadji dan Sopiah (2013:100-101) mengemukakan lima dimensi kualitas jasa yaitu :

1) Kehandalan (reliability)

2) Daya tanggap (responsiveness)

3) Jaminan (assurance)

4) Empati

5) Produk-produk fisik (tangibles)

\section{Kepuasan Pelanggan}

Kotler (2014:150) mengemukakan bahwa pengertian kepuasan pelanggan ialah perasaan senang atau kecewa yang muncul stelah membandingkan kinerja (hasil) produk yang dipikirksn terhadap kinerja (atau hasil) yang diharapkan. Lovelock dan Wirtz (2011:74) kepuasan addalah suatu sikap yang diputuskan berdasarkan pengalaman yang di dapatkan. Kepuasan merupakan penilaian mengenai ciri atau keistimewaan produk atau jasa, atau produk itu sendiri, yang menyediakan tingkat kesenangan konsumen berkaitan dengan pemenuhan kebutuhan konsumsi konsumen. Kepuasan konsumen dapat diciptakan melalui kualitas, pelayanan, dan nilai. Kunci untuk menghasilkan kesetiaan pelanggan adalah memberikan nilai pelanggan yang tinggi.

Usaha mempertahankan pelanggan melibatkan berbagai pertimbangan sebagai berikut:

1) Penilaian pelanggan, menggambarkan bagaimana penilaian pelanggan dan mengelompokkan mereka menurut nilai finansial dan strategisnya, sehingga perusahaan dapat memutuskan dimana harus berinvestasi untuk menjalin hubungan yang lebih dalam dan hubungan mana yang perlu dilayani secara berbeda atau bahkan dibatasi.

2) Pengukuran costumer retention, menggambarkan persentase jumlah pelanggan yang masih bertahan dalam menggunakan produk atau jasa perusahaan.

3) Menentukan alasan untuk perpindahan. Jika pelanggan meninggalkan perusahaan, harus dilihat akar penyebabnya. Hal ini membutuhkan pemeriksaan secara detail ketika berbicara dengan pelanggan sebelumnya. Teknik-teknik lain juga juga dimasukkan dalam menganalisis komplain dari pelanggan.

4) Mengembangkan dan menerapkan rencana perbaikan. Hal ini melibatkan berbagai tindakan untuk meningkatkan praktek kerja, menggunakan standar untuk menentukan praktek perbaikan yang terbaik, dukungan yang jelas dari top manajemen, penyesuaian dengan sistem pengakuan dan balas jasa perusahaan, dan penggunaan tim recovery untuk menghilangkan penyebab perpindahan pelanggan.

Menurut Kotler (2008:197) kepuasan pelanggan merupakan tingkat perasaan setelah membandingkan kinerja hasil yang ia rasa dibandingkan dengan harapannya. Adapun indikator dalam kepuasan pelanggan adalah sebagai berikut :

1. Pelayanan memuaskan.

2. Pelayan sesuai yang diharapkan.

3. Permasalahan terselesaikan.

4. Kesediaan merekomendasikan.

5. Minat pengguna ulang. 


\section{Pengaruh Kualitas Pelayanan Terhadap Kepuasan Konsmen}

Salah satu kemungkinan hubungan yang banyak disepakati adalah kepuasan membantu konsumen dalam merevisi persepsinya terhadap kualitas jasa. Dasar pemikiran seperti dikemukakan oleh Fandy Tjiptono dan Gregorius Chandra (2005:209) yaitu :

1. Bila konsumen tidak memiliki pengalaman sebelumnya dengan suatu perusahaan, maka persepsinya terhadap kualitas jasa perusahaan tersebut akan didasarkan pada ekspektasinya

2. Interaksi (service encounter) berikutnya dengan perusahaan tersebut akan menyebabkan konsumen memasuki proses diskonfirmasi dan merevisi persepsinya terhadap kualitas jasa.

3. Persepsi interaksi tambatan dengan persalinan itu akan memperkuat atau sebaliknya malah mengubah persepsi pelanggan terhadap kualitas jasa.

4. Persepsi terhadap kualitas jasa yang telah direvisi memodifikasi minat jadi konsumen terhadap perusahaan di masa yang akan datang.

Dari definisi yang telah dikemukakan dapat disimpulkan bahwa hubungan kualitas antara konsumen dan kualitas jasa diintegrasikan dengan cara menetukan dua variabel yaitu jasa yang dirasakan (perceived service) dan jasa yang diharapkan (expected service). Bila jasa yang dirasakan lebih kecil dari pada yang diharapkan, maka para pelanggan menjadi tidak tertarik lagi pada penyedia jasa yang bersangkutan (Tjiptono, 2008:146)

\section{Kerangka Pemikiran}

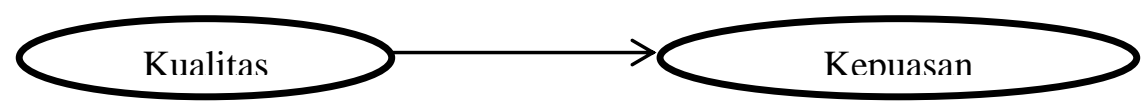

\section{Gambar 1. Hubungan antara Kualitas Pelayanan dengan Kepuasan Konsumen}

\section{Hipotesis}

Berdasarkan uraian pada kerangka, dan tujuan penelitian diatas serta untuk menjawab perumusan masalah, maka penulis dapat menyatakan suatu hipotesis sebagai berikut. Diduga bahwa kualitas pelayanan berpengaruh terhadap kepuasan konsumen pada Labersa Grand Hotel \& Convention Center Kampar.

\section{METODE PENELITIAN}

Penelitian ini dilakukan pada Labersa Grand Hotel \& Convention Center, Siak Hulu, Kampar-Riau. Jenis dan Sumber data yang diperlukan dalam penelitian ini adalah data primer dan data sekunder. Dalam penelitian ini populasinya adalah tamu yang menggunakan ruangan pesta/Ballroom dan Ruang Meeting pada Labersa Grand Hotel \& Convention Center yang berjumlah 1.317 orang Jumlah sampel diperoleh dengan menggunakan rumus Slovin, atas dasar rumus tersebut maka peneliti menetapkan jumlah sampel sebanyak 92,94 orang, dalam hal ini peneliti akan menyebarkan angket penelitian sebanyak 93 orang. Menurut Sugiono (2010:116), teknik sampling merupakan teknik pengambilan sampel. Metode penarikan sampel yang digunakan adalah teknik probability sampling yaitu teknik pengambilan sampel yang memberikan peluang yang sama bagi setiap unsur populasi untuk dipilih menjadi anggota sampel. Simpel random sampling dikatakan sederhana, karena pengambilan anggota yang dilakukan secara acak tanpa mempengaruhi strata yang ada dalam populasi itu. Analisis dalam penelitian ini adalah Regresi Linear Sederhana menggunakan bantun program SPSS 
V.22 yang menguji: uji Kualitas Data, Uji Reliabilitas, Uji Asumsi Klasik dan Uji Hipotesis serta Koefisien Determinasi.

\section{HASIL DAN PEMBAHASAN \\ Uji Validitas}

Validitas adalah ketepatan atau kecermatan suatu instrument dalam mengukur apa yang ingin diukur. Pengujian validitas dilakukan dengan metode Corrected Item-Total Correlation, nilai tersebut kemudian dibandingkan dengan nilai $r$ tabel dicari dengan signifikansi 0,05 dengan jumlah data $(n-2)=93-2=91$, maka $r_{-}$tabel 0,2039.

Tabel 4. Uji Validitas Variabel Kualitas Pelayanan

\begin{tabular}{|l|l|l|l|}
\hline Item pernyataan & r_hitung & r_tabel & Keterangan \\
\hline Pernyataan Kualitas Pelayanan yang ke_1 & 0,509 & 0,2039 & Valid \\
\hline Pernyataan Kualitas Pelayanan yang ke_2 & 0,566 & 0,2039 & Valid \\
\hline Pernyataan Kualitas Pelayanan yang ke_3 & 0,512 & 0,2039 & Valid \\
\hline Pernyataan Kualitas Pelayanan yang ke_4 & 0,527 & 0,2039 & Valid \\
\hline Pernyataan Kualitas Pelayanan yang ke_5 & 0,568 & 0,2039 & Valid \\
\hline Pernyataan Kualitas Pelayanan yang ke_6 & 0,513 & 0,2039 & Valid \\
\hline Pernyataan Kualitas Pelayanan yang ke_7 & 0,505 & 0,2039 & Valid \\
\hline Pernyataan Kualitas Pelayanan yang ke_8 & 0,527 & 0,2039 & Valid \\
\hline Pernyataan Kualitas Pelayanan yang ke_9 & 0,536 & 0,2039 & Valid \\
\hline Pernyataan Kualitas Pelayanan yang ke_10 & 0,501 & 0,2039 & Valid \\
\hline
\end{tabular}

Sumber :Hasil SPSS, 2019

Dari tabel 4 dapat dilihat nilai $\mathrm{r}$ _hitung untuk masing-masing item pernyataan pada variabel kualitas pelayanan lebih besar ( $>$ ) dari nilai r_tabel $(0,2039)$, maka dapat disimpulkan bahwa data sudah sesuai dengan keadaan yang sebenarnya atau data sudah valid. Item pernyataan yang memiliki nilai $r$ _hitung yang paling tinggi pada variabel kualitas pelayanan adalah item pernyataan pada butir ke 5, yaitu sebesar 0,568.

Tabel 5. Uji Validitas Variabel Kepuasan Konsumen

\begin{tabular}{|l|l|l|l|}
\hline Item pernyataan & r_hitung & r_tabel & Keterangan \\
\hline Pernyataan Kepuasan Konsumen yang ke_1 & 0,527 & 0,2039 & Valid \\
\hline Pernyataan Kepuasan Konsumen yang ke_2 & 0,513 & 0,2039 & Valid \\
\hline Pernyataan Kepuasan Konsumen yang ke_3 & 0,511 & 0,2039 & Valid \\
\hline Pernyataan Kepuasan Konsumen yang ke_4 & 0,532 & 0,2039 & Valid \\
\hline Pernyataan Kepuasan Konsumen yang ke_5 & 0,562 & 0,2039 & Valid \\
\hline Pernyataan Kepuasan Konsumen yang ke_6 & 0,570 & 0,2039 & Valid \\
\hline Pernyataan Kepuasan Konsumen yang ke_7 & 0,525 & 0,2039 & Valid \\
\hline Pernyataan Kepuasan Konsumen yang ke_8 & 0,510 & 0,2039 & Valid \\
\hline Pernyataan Kepuasan Konsumen yang ke_9 & 0,564 & 0,2039 & Valid \\
\hline Pernyataan Kepuasan Konsumen yang ke_10 & 0,507 & 0,2039 & Valid \\
\hline Surang
\end{tabular}

Sumber : Hasil SPSS, 2019

Dari tabel 5 dapat dilihat nilai $\mathrm{r} \_$hitung untuk masing-masing item pernyataan pada variabel kepuasan konsumen lebih besar (>) dari nilai $r_{-}$tabel $(0,2039)$, maka dapat disimpulkan bahwa data sudah sesuai dengan keadaan yang sebenarnya atau data sudah valid. 
Volume VIII, No. 01, September 2019

Item pernyataan yang memiliki nilai $\mathbf{r}$ _hitung yang paling tinggi variabel kepuasan konsumen adalah item pernyataan pada butir ke 6 , yaitu sebesar 0,570 .

\section{Uji Reliabilitas}

Uji reliabilitas digunakan untuk mengetahui apakah jawaban responden dari waktukewaktu memiliki jawaban yang sama/konsisten atau tidak. Dalam penelitian ini metode yang digunakan adalah dengan metode Cronbach's Alpha yang mensyaratkan nilai Cronbach's Alpha $>0,60$ maka data adalah reliabel atau dapat dipercaya. Berikut hasil uji reliabilitas:

Tabel 6. Uji Reliabilitas

\begin{tabular}{|l|l|l|}
\hline Variabel & Cronbach's Alpha & Keterangan \\
\hline Kualitas Pelayanan & 0,836 & Reliabel \\
\hline Kepuasan Konsumen & 0,839 & Reliabel \\
\hline
\end{tabular}

Sumber : Hasil SPSS 2019

Dari tabel 6 dapat dijelaskan bahwa variabel kualitas pelayanan memiliki nilai sebesar 0,836 dan variabel kepuasan konsumen sebesar 0,839 Karena nilai lebih besar dari 0,60 maka dapat disimpulkan bahwa semua variabel dalam penelitian ini adalah reliabel atau konsisten, artinya semua pernyataannya dapat dipercaya.

\section{Normalitas}

Berikut adalah hasil uji normalitas data, yaitu sebagai berikut.

Normal P-P Plot of Regression Standardized Residual

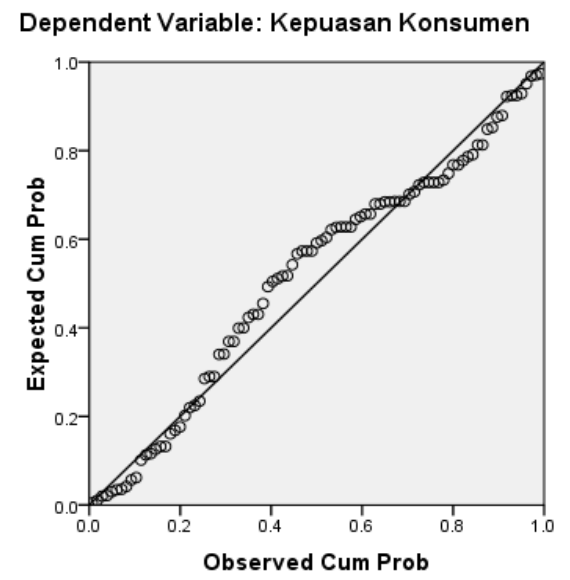

Sumber: Hasil SPSS, 2019

Gambar 2 Uji Normalitas

Dari gambar diatas, maka dapat dilihat bahwa sebaran data mendekati garis diagonal, maka dapat disimpulkan bahwa data sudah berdistribusi normal. Berdasarkan hasil uji validitas, reliabilitas, dan uji normalitas, maka dapat disimpulkan bahwa data sudah layak atau data sudah dapat digunakan dalam penelitian ini. 
Volume VIII, No. 01, September 2019

\section{Regresi Linear Sederhana}

Analisis regresi linier Sederhana digunakan untuk menentukan arah hubungan yang linier antara variabel bebas terhadap variabel terikat:

Tabel 7. Analisis Regresi Linier Sederhana

\begin{tabular}{|l|l|l|l|l|l|l|}
\hline \multirow{2}{*}{ Model } & \multicolumn{2}{l|l}{$\begin{array}{l}\text { Unstandardized } \\
\text { Coefficients }\end{array}$} & \multicolumn{2}{l|}{$\begin{array}{l}\text { Standardized } \\
\text { Coefficients }\end{array}$} & & \\
\cline { 3 - 7 } & B & Std. Error & Beta & t & Sig. \\
\hline \multirow{2}{*}{1} & (Constant) & 16.974 & 3.416 & & 4.969 & .000 \\
\cline { 2 - 5 } & Kualitas Pelayanan & .642 & .083 & .629 & 7.722 & .000 \\
\hline
\end{tabular}

a. Dependent Variable: Kepuasan Konsumen

Sumber : Hasil SPSS, 2019

Berdasarkan tabel 7 diperoleh persamaan regresi linier sederhana adalah sebagai berikut: $\mathrm{Y}=16,974+0,642 \mathrm{X}$. Persamaan tersebut dapat diartikan sebagai berikut, nilai sebesar 16.974 artinya tanpa adanya kualitas pelayanan, atau nilai kualitas pelayanan $=$ nol (0) maka kepuasan konsumen sebesar 16.974 satuan. Dan nilai koefisien regresi kualitas pelayanan sebesar 0,642 menunjukkan jika variabel kualitas pelayanan dinaikan 1 satuan, maka kepuasan konsumen akan meningkat sebesar 0,642 satuan.

Berdasarkan hasil regresi sederhana diatas, maka dapat disimpulkan bahwa arah hubungan variabel kualitas pelayanan terhadap variabel kepuasan konsumen memiliki arah hubungan yang positif, jika variabel bebas dalam hal ini kualitas pelayanan meningkat, maka variabel terikat dalam hal ini kepuasan konsumen juga akan meningkat.

\section{Hasil Uji t}

Pembuktian Hipotesis ini dilakukan untuk melihat pengaruh variabel bebas secara sendiri-sendiri terhadap variabel terikatnya, sehingga nantinya dapat diketahui apakah hipotesi H0 diterima atau ditolak. Berikut adalah hasil output untuk uji_t menggunakan bantuan program SPSS, yaitu :

Tabel 8. Uji t

\begin{tabular}{|c|c|c|c|c|c|c|}
\hline \multirow{2}{*}{\multicolumn{2}{|c|}{ Model }} & \multicolumn{2}{|c|}{$\begin{array}{l}\text { Unstandardized } \\
\text { Coefficients }\end{array}$} & \multirow{2}{*}{\begin{tabular}{|l} 
Standardized \\
Coefficients \\
Beta \\
\end{tabular}} & \multirow[b]{2}{*}{$\mathrm{t}$} & \multirow[b]{2}{*}{ Sig. } \\
\hline & & B & Std. Error & & & \\
\hline \multirow[t]{2}{*}{1} & (Constant) & 16.974 & 3.416 & & 4.969 & .000 \\
\hline & Kualitas Pelayanan & .642 & .083 & .629 & 7.722 & .000 \\
\hline
\end{tabular}

a. Dependent Variable: Kepuasan Konsumen

Sumber : Hasil SPSS, 2019

Dari tabel 8 maka dapat dibuktikan kebenaran dari hipotesis yang penulis ajukan pada bab sebelumnya. Uji_t ini dilakukan dengan membandingkan t-hitung dengan dengan t-tabel pada signifikan 5\% $(\alpha=0,05)$. Untuk nilai t tabel diperoleh sebagai berikut : $\mathrm{n}-2$ (baris), $1 / 2 \alpha$ (kolom) maka diperoleh 93-2=91 (baris) dan $1 / 2 \alpha=0,025$ (kolom, sehingga nilai t_tabel diperoleh sebesar 1,98638.

Berdasarkan hasil olah data diperoleh nilai t-hitung sebesar 7,722 sedangkan untuk nilai t_tabel diperoleh sebesar 1,98638 maka hal ini dapat dijelaskan bahwa nilai t_hitung $(7,722)$ > dari t_tabel $(1,98638)$, sehingga dapat disimpulkan bahwa ada pengaruh yang signifikan antara kualitas pelayanan terhadap kepuasan konsumen perusahaan Banquet Labersa Grand Hotel \& Convention Center. 


\section{Koefesien Determinasi}

Koefisien determinasi menunjukkan seberapa besar pengaruh variabel bebas terhadap variabel terikat. Berikut adalah hasil output koefesien determinasi.

Tabel 9. Koefesien Determinasi

\begin{tabular}{|l|l|l|l|l|}
\hline & & & & \\
Model & R & R Square & Adjusted R Square & Std. Error of the Estimate \\
\hline 1 & $.629^{\mathrm{a}}$ & .396 & .389 & 4.56153 \\
\hline
\end{tabular}

a. Predictors: (Constant), Kualitas Pelayanan

b. Dependent Variable: Kepuasan Konsumen

Sumber : Hasil SPSS, 2019

Berdasarkan tabel 5.32 maka dapat diperoleh $\mathrm{R}$ sebesar 0,629 hal ini berarti kualitas pelayanan memiliki hubungan yang erat terhadap kepuasan konsumen. Sedanhgkan nilai R_square atau koefesien determinasi sebesar 0,396 yang memiliki arti besarnya pengaruh variabel bebas/ kualitas pelayanan terhadap variabel terikat/ kepuasan konsumen sebesar $39,6 \%$ sedangkan sisanya sebesar $60,4 \%$ dipengaruhi oleh variabel bebas lainnya yang tidak diamati dalam penelitian ini. Contohnya adalah promosi, harga, dan lain-lainnya.

\section{PENUTUP}

\section{Kesimpulan}

Berdasarkan hasil yang diperoleh, maka dapat ditarik suatu kesimpulan dalam penelitian ini, yaitu :

1. Hasil uji validitas, reliabilitas, dan hasil uji normalitas data sudah sesuai, maka dapat disimpulkan bahwa data sudah dapat digunakan dalam penelitian

2. Hasil regresi linier sederhana dengan persamaan sebagi berikut $Y=16,974+0,642 \mathrm{X}$ maka dapat disimpulkan bahwa variabel bebas memiliki arah hubungan positif.

3. Hasil uji_t diperoleh variabel bebas berpengaruh signifikan terhadap variabel terikat yaitu dapat dilihat nilai t_hitung $(7,722)>$ dari t_tabel $(1,98638)$.

4. Koefisien Determinasi memiliki nilai sebesar 0,396 artinya besarnya pengaruh/sumbangan atau kontribusi yang diberikan variabel bebas terhadap variabel terikat sebesar 39,6\% sedangkan sisanya sebesar 60,4\% dipengaruhi oleh faktor-faktor lain yang tidak masuk dalam penelitian ini.

5. Rata-rata hasil tanggapan variabel kualitas pelayanan pada kuisioner adalah 4,07 (Setuju), dan rata-rata hasil tanggapan variabel kepuasan konsumen pada kuisioner adalah 4,31 (Sangat Setuju).

\section{Saran}

Berdasarkan hasil penelitian dan kesimpulan di atas, saran-saran yang diajukan dalam penelitian ini sebagai berikut :

1. Karyawan Banquet Labersa Grand Hotel \& Convention Center harus lebih meningkatkan serta memberikan jaminan pelayanan yang baik kepada konsumen.

2. Manajemen harus meningkatkan rasa aman dan nyaman kepada konsumen yang akan mengadakan acara di Banquet Labersa Grand Hotel \& Convention Center, dengan menetapkan beberarapa security di beberapa tempat yang dianggap rawan.

3. Karyawan Banquet harus meningkatkan pelayanan serta memberikan pelayanan secara adil dan tidak membedakan status sosial konsumen. 
Volume VIII, No. 01, September 2019

\section{REFERENCE}

Alma, Buchari 2014. Manajemen Pemasaran Jasa. Bandung : Alfabeta

Batinggi, A. dan Badu Ahmad, 2013. Manajemen Pelayanan Publik. Yogyakarta : Andi Offset.

Catur Wulandari Shinta, 2016 Pengaruh Kualitas Pelayanan Terhadap Kepuasan Pelanggan Pada PT. Ibrahim Abdullah Budi Mulia Cabang Pekanbaru, STIE RIAU.

Ghozali, Iman. 2005, Aplikasi Analisis Multivariate dengan Program SPSS. Cetakan IV. Badan Penerbit Universitas Diponegoro Semarang

Hermanto, Apriansyah, R., Fikri, K., \& Albetris. (2019). Pengaruh Lokasi dan Kualitas Pelayanan Terhadap Loyalitas Konsumen pada Fotocopy Anugrah Rengat. Ekonomis: Journal of Economics and Business, 3(2), 171-176. https://doi.org/10.33087/ekonomis.v3i2.78

Manik, S. (2016). PENGARUH KUALITAS PELAYANAN TERHADAP KEPUASAN PASIEN PADA RUMAH SAKIT THURSINA DI DURI. Eko dan Bisnis: Riau Economic and Business Review, 7(1), 80-93. https://doi.org/10.1017/CBO9781107415324.004

Kotler dan Amstrong, 2012. Prinsip-prinsip Marketing. Edisi 13 Jilid 1. Jakarta : Erlangga

Kotler, 2012, Dasar Dasar Pemasaran, Jakarta ; CV Intermedia

Kottler Philip, 2009. Manajemen pemasaran. Jilid I. PT. Gelora Aksara Pratama

Lupiyoadi Rambat, 2001. Manajemen Pemasaran Jasa. Salemba empat. Jakarta

Masrum, W.A.Restoran dan segala permasalahannya, Jakarta: Andi, Ofseet.

Moenir A.S 2014. Manajemen Pelayanan Umum di Indonesia. Jakarta. Pustaka Pelajar

Rosita Lakmi Ade, 2015 Pengaruh Kualitas Pelayanan Terhadap Kepuasan Masyarakat Pada Rumah Sakit Umum Daerah Bandung, Universitas Udayana.

Sanjaya Andi, 2017 Pengaruh Kualitas Pelayanan Terhadap Kepuasan Konsumen Pada PT. First Indo American Leasing Cabang Pekanbaru, STIE RIAU.

Sopiah dan Sangadji, 2013. Perilaku Konsumen. CV. Andi Offset. Yogyakarta

Sudaryono, 2016. Manajemen Pemasaran Teori \& Implementasi. Yogyakarta : CV. Andi Offset

Sugiyono, 2013, Metodelogi Penelitian Kuantitatif, Kualitatif dan R\&D, Alfabeta, Bandung

Sumarni, Murni. Soeprihantono, Jhon, 2010. Pengantar Bisnis (dasar-dasar ekonomi perusahaan). Yogyakarta :Liberty

Sumarni, Murni. Soeprihantono, Jhon, 2010. Pengantar Bisnis (dasar-dasar ekonomi perusahaan). Yogyakarta :Liberty

Suryani, Tatik, 2008. Perilaku Konsumen : Implikasi pada Pemasaran, Graha Ilmu. Yogyakarta

Tjiptono Fandy, 2012. Strategi Pemasaran. Edisi III. CV. Andi Offset. 